Vol. 1 No. 3 Desember 2021 e-ISSN : 2797-3344 P-ISSN : 2797-3336

\title{
PENINGKATAN KOMPETENSI GURU KELAS TINGGI DALAM MENYUSUN ADMINISTRASI PEMBELAJARAN MELALUI SUPERVISI AKADEMIK DI SDN 2 WANASABA DAYA MASA PANDEMI COVID-19 TAHUN PELAJARAN 2021/2022
}

\author{
SAHUDIN \\ SDN 2 Wanasaba Kabupaten Lombok Timur \\ sahudin012@gmail.com
}

\begin{abstract}
ABSTRAK
Tujuan dari penelitian tindakan sekolah (PTS) ini adalah untuk mengetahui sejauh mana supervisi yang dilakukan oleh kepala sekolah yang diikuti dengan pemberian pembinaan/perlakuan terhadap guru-guru sasaran dapat meningkatkan kemampuannya dalam menyusun administrasi pembelajaran dan mampu menuangkannya dalam proses pembelajaran. Kegiatan penelitian tindakan sekolah ini dilakukan di SDN 2 Wanasaba Daya selama 3 bulan yaitu mulai bulan Juli Agustus sd. September 2021 dengan melalui tahapan-tahapan siklus. Dalam penelitian tindakan sekolah (PTS) ini dilakukan dalam 2 siklus, dari hasil tindakan yang dilakukan terbukti dapat meningkatkan kemampuan guru dengan mencapai standar ideal. Pada siklus I peningkatan kemampuan guru setelah dilakukan supervisi kelas setelah dilakukan pembinaan tentang pemanfaatan media pembelajaran baru mencapai sekitar $66,67 \%$ pada siklus II dapat meningkat menjadi $100 \%$. Skor rata-rata yang diperoleh setelah dilakukan supervisi kelas pada siklus I sebesar 73 dan meningkat pada siklus II menjadi 85, berarti ada peningkatan sebesar $12 \%$ dan tingkat ketuntasan secara kelompok/klasikal pada siklus I mencapai $66,67 \%$ dan pada siklus II meningkat menjadi $100 \%$. Hasil penelitian tindakan sekolah ini menunjukkan bahwa pembinaan kepala sekolah dapat meningkatkan kemampuan guru dalam menggunakan media pembelajaran pada proses pembelajarannya.
\end{abstract}

Kata Kunci: kompetensi guru, supervisi akademik

\section{ABSTRACT}

The purpose of this school action research (PTS) is to find out the extent to which the supervision carried out by the principal followed by the provision of guidance/treatment to the target teachers can improve their ability to develop learning administration and be able to put it into the learning process. This school action research activity was carried out at SDN 2 Wanasaba Daya for 3 months, starting from July to August until. September 2021 by going through the stages of the cycle. In this school action research (PTS) it was conducted in 2 cycles, from the results of the actions taken it was proven to be able to improve the ability of teachers by achieving ideal standards. In the first cycle the increase in teacher ability after classroom supervision was carried out after coaching on the use of new learning media reached around $66.67 \%$ in the second cycle it could increase to $100 \%$. The average score obtained after class supervision in the first cycle was 73 and increased in the second cycle to 85, meaning that there was an increase of $12 \%$ and the group/classical completeness level in the first cycle reached $66.67 \%$ and in the second cycle increased to $100 \%$. The results of this school action research indicate that the coaching of the principal can improve the ability of teachers to use learning media in the learning process.

Keywords: teacher competence, academic supervision

\section{PENDAHULUAN}

Pendidikan merupakan usaha sadar yang dilakukan orang dewasa untuk menumbuhkembangkan potensi sumberdaya manusia melalui kegiatan pengajaran. Kegiatan pengajaran tersebut diselenggarakan pada semua satuan dan jenjang pendidikan yang berlaku diberikan kepada peserta didik untuk menuju ke arah kedewasaan yang wajar (Mulia, dkk, 2016). Hal ini sesuai dengan tujuan pendidikan Nasional yang tercantum dalam Undangundang Republik Indonesia No. 20 Tahun 2003 Bab II pasal 3 yang berbunyi: pendidikan 
Nasional berfungsi untuk mengembangkan kemampuan dan membentuk watak serta peradaban bangsa yang bermartabat dalam rangka mencerdaskan kehidupan bangsa dan bertujuan untuk mengembangkan potensi peserta didik agar menjadi manusia yang beriman dan bertaqwa Kepada Tuhan Yang Maha Esa.

Ki Hajar Dewantara mengemukakan bahwa pendidikan adalah proses pembudayaan yakni suatu usaha memberikan nilai-nilai luhur kepada generasi baru dalam masyarakat yang tidak hanya bersifat pemeliharaan tetapi juga dengan maksud memajukan serta memperkembangkan kebudayaan menuju ke arah keluhuran hidup manusia. Dan menurut UU SISDIKNAS no. 20 tahun 2003: Pendidikan adalah usaha sadar dan terencana untuk mewujudkan suasana belajar dan proses pembelajaran agar peserta didik secara aktif mengembangkan potensi dirinya untuk memiliki kekuatan spiritual keagamaan, pengendalian diri, kepribadian, kecerdasan, akhlak mulia, serta keterampilan yang diperlukan dirinya dan masyarakat.

Dari pengertian di atas pendidikan merupakan proses pengubahan sikap dan perilaku seseorang menuju kedewasaan dan ke arah yang lebih sempurna melalui upaya pengajaran dan pelatihan. Sesuai dengan Undang-undang No. 20 Tahun 2003 tentang Sistem Pendidikan Nasional, jabatan guru sebagai pendidik merupakan jabatan professional. Guru yang profesional adalah orang yang memilki kemapuan atau keahlian khusus dalam bidang keguruan (pembelajaran) diantaranya menyusun adminstrasi pembelajaran sebagai acuan dalam proses pembelajaran sehingga proses pembelajaran menjadi terarah, terukur dan berjalan sebagaimana mestinya (Kau, 2017). Di dalam menyusun adminstrasi pembelajaran guru harus mampu menyesuaikan situasi dan kondisi, seperti kondisi saat ini negara sedang mengalami musibah pandemi Covid-19 (virus Corona).

Berdasar Surat Edaran No. 4 tahun 2020 yang dikeluarkan oleh Menteri Pendidikan dan Kebudayaan Republilk Indonesia "Kesehatan lahir dan batin siswa, guru, kepala sekolah dan seluruh warga sekolah menjadi pertimbangan utama dalam pelaksanaan kebijakan menjaga jarak agar rantai penyebaran terputus". Penutupan sementara lembaga pendidikan sebagai upaya menahan penyebaran pendemi Covid-19 di negara tercinta ini berdampak pada jutaan peserta didik. Kondisi ini memaksa guru untuk melakukan pembelajaran jarak jauh hal ini menuntut guru harus mampu menyusun prangkat pembelajaran yang sesuai dengan kondisi.

Keberhasilan siswa dalam belajar sangat dipengaruhi oleh bagaimana cara guru mengajar. Guru tidak hanya berfungsi mentransfer pengetahuan saja tetapi juga bertugas untuk memberikan keterampilan, merubah perilaku peserta didik. Untuk itu diperlukan guru yang profesional dalam pendidikan (Yuhana, dkk, 2019). Oleh karena itukompetensi guru harus terus menerus dibina dan dikembangkan sehingga guru mampu menghasilkan pendidikan yang bermutu (Astuti, 2016).

Menurut Hamid (2017), Supervisi akademik adalah serangkaian kegiatan membantu guru mengembangkan kemampuannya mengelola proses pembelajaran untuk mencapai tujuan pembelajaran. Sehingga supervisi akademik bukan menilai unjuk kerja guru melainkan membantu guru guna mengembangkan kemampuan profesionalnya (Sudirman, 2020). Walaupun demikian kegiatan supervisi akademik tidak dapat terlepas dari penilaian unjuk kerja guru dalam mengelola kegiatan belajar mengajar (Susetya, 2017). Agar kegiatan supervisi akademik dapat berfungsi dan mempunyai arah yang baik dalam membantu guru mengembangkan atau meningkatkan kompetensinya terlebih dahulu perlu diadakan penilaian kemampuan guru supaya dapat ditetapkan aspek kekurangan yang perlu dikembangkan (Gabena, 2017).

Dalam prakteknya di lapangan, Kepala madrasah menghadapi tanggung jawab yang berat, untuk itu ia harus memiliki persiapan memadai dalam melaksanakan pekerjaannya, khususnya dalam meningkatkan kompetensi tenaga pendidik di lembaga yang dipimpinnya, sehingga mampu menciptakan suasana pendidikan dan pembelajaran yang efektif dan efisien (Fitrah, 2017). Hal ini diperlukan, mengingat guru merupakan ujung tombak dari kegiatan pendidikan dan pembelajaran yang menjadi motivator bagi peserta didik dalam memacu 
aktivitas belajarnya (Manizar, 2015). Guru merupakan sosok yang menjadi panutan atau uswah hasanah yang mampu mengarahkan dan mengubah perilaku dan karakter peserta didik kea rah yang lebih baik (Minsih, 2018). Bahkan lebih dari itu, guru merupakan orang yang paling bertanggung jawab dalam melahirkan generasi penerus bangsa yang memiliki keilmuan, akhlakul karimah dan kedalaman spiritual yang menjadi ujung tombak bagi kemajuan suatu bangsa (Baharun, 2018).

Secara umum guru SDN 2 Wanasaba Daya dalam kegiatan belajar mengajar belum optimal seperti yang diharapkan, dimana masih ada beberapa guru dalam mengajar di kelas hanya membawa buku materi ajar dan tidak membawa perangkat pembelajaran seperti Rencana Pelaksanaan Pembelajaran, silabus, daftar hadir, daftar nilai. Untuk itu guna mencapai profesionalisme dari seorang guru tanpa mengabaikan berbagai faktor seperti ekonomi dan geografis maka faktor pengelolaan supervisi akademik yang dilakukan kepala sekolah diharapkan mempunyai pengaruh yang signifikan kepada peningkatan kualitas pendidikan terutama kompetensi guru dalam pembelajaran.

Berdasarkan hal-hal tersebut di atas peneliti mengadakan sebuah penelitian tindakan sekolah dengan judul "Peningkatan Kompetensi Guru Kelas Tinggi dalam menyusun admisitrasi pembelajaran di SDN 2 Wanasaba Daya Masa Pandemi Covid-19 Semester I Tahun Pelajaran 2021/2022”

\section{METODE PENELITIAN}

Jenis penelitian ini adalah penelitian tindakan Sekolah (PTS). Penelitian tindakan sekolah (PTS) merupakan suatu proses investigasi terkendali yang berdaur ulang dan bersifat reflektif mandiri yang dilakukan oleh kepala sekolah yang memiliki tujuan untuk melakukan perbaikan-perbaikan terhadap sistem, cara kerja, proses, isi, Kemampuan, atau situasi pembelajaran. Penelitian tindakan sekolah (PTS) dan dilaksanakan pada semester ganjil tahun pelajaran 2021/2022 ini.

Penelitian tindakan sekolah ini dilaksanakan di SDN 2 Wanasaba Daya Kecamatan Wanasaba Kabupaten Lombok Timur yang merupakan tempat tugas peneliti. Penelitian ini dilaksanakan dengan menggunakan dua siklus, dengan setiap siklusnya dilaksanakan proses pembimbingan berupa Pembuatan administrasi pembelajaran kemudian dilaksanakan observasi/penilaian berupa supervisi proses pembelajaran. Penelitian ini dilaksanakan selama kurang lebih tiga bulan, yaitu mulai bulan Juli sampai dengan September 2021.

Subyek penelitian adalah guru-guru SDN 2 Wanasaba Daya Kecamatan Wanasaba Kabupaten Lombok Timur tahun pelajaran 2021/2022 yang berjumlah 3 orang guru Kelas Tinggi. Pada penelitian tindakan sekolah ini, memiliki ciri utama yaitu terdapat siklus-siklus yang tiap siklusnya memiliki tahapan-tahapan yaitu: a) perencanaan tindakan (planning), b) tindakan (acting), c) pengamatan (observasing), d) refleksi (reflecting). Sumber data penelitian ini berasal dari peneliti, observer, dan guru sasaran penelitian pada semester ganjil di SDN 2 Wanasaba Daya kecamatan Wanasaba.

\section{HASIL DAN PEMBAHASAN}

\section{Siklus I}

Tahap Perencanaan, Pada tahap ini peneliti mempersiapkan perangkat pembinaan yang terdiri dari rencana pembinaan 1, Instrumen 1, Evaluasi 1 dan alat-alat pembinaan yang mendukung. Selain itu juga dipersiapkan lembar observasi pengolaan pembelajaran.

Tahap Kegiatan dan Pelaksanaan, Pelaksanaan kegiatan pembinaan untuk siklus I dilaksanakan tanggal 22 s.d 31 Agustus 2021 di SDN 2 Wanasaba Daya kecamatan Wanasaba dengan jumlah guru 3 Orang. Dalam hal ini peneliti bertindak sebagai Kepala Sekolah. Adapun proses pembinaan mengacu pada rencana pelajaran yang telah dipersiapkan. Pengamatan (observasi) dilaksanakan bersamaan dengan pelaksaaan belajar mengajar. Pada akhir proses pembinaan, guru dan kepala sekolah menyepakati waktu pelaksanaan supervisi di kelas dengan 
tujuan untuk mengetahui tingkat kemampuan guru dalam proses belajar mengajar yang telah dilakukan.

Tabel 1 Tabel hasil Supervisi Akademik Pada Siklus I

\begin{tabular}{llccc}
\hline & \multicolumn{1}{c}{ Nama Guru } & Skor & Keterangan \\
No & & 67 & & Tuntas \\
Tidak Tuntas \\
$2 \quad$ Sahibul Fadli, S.Pd.I. & 78 & $\sqrt{ }$ & \\
3 & Subki, S.Pd. & 75 & $\sqrt{ }$ & \\
Jumlah Nilai & 220 & - & - \\
Nilai rata-rata & 73 & - & - \\
$\%$ Jumlah Guru Yang Mencapai & $66,67 \%(=2$ guru $)$ & \\
nilai Supervisi Akademik minimal \\
75
\end{tabular}

Dari tabel di atas dapat dijelaskan bahwa dengan menerapkan supervisi akademik kepala sekolah diperoleh nilai rata-rata kemampuan guru adalah 66,67 dan ada 2 orang guru dari 3 orang sudah tuntas dalam penyusunan administrsi dan dapat mengaplikasikannya dalam proses belajar mengajar. Namun hasil tersebut menunjukkan bahwa pada siklus pertama secara kelompok guru (sekolah) belum menunjukkan peningkatan secara signifikan, karena guru yang memperoleh nilai $\geq 75$ memiliki nilai rata-rata sebesar 66,66\% artinya lebih kecil dari persentase ketuntasan yang dikehendaki yaitu sebesar $\geq 85 \%$. Hal ini disebabkan karena guru tersebut masih pertama kali diberikan pembekalan dalam penyusunan administrasi pembelajaran terlebih lagi dalam proses pembelajaran yang bersangkutan masih agak kaku dan mengalami kesulitan dalam penyampaian materi pembelajaran.

Refleksi, Dalam pelaksanaan kegiatan belajar mengajar diperoleh informasi dari hasil pengamatan sebagai berikut: 1) Kepala Sekolah kurang maksimal dalam mengarahkan guru untuk membuat administrasi pembelajaran, 2) Pelaksanaan supervisi yang masih belum maksimal, 3) Guru kurang mampu dalam penyusunan adminstrasi, 4) Guru masih belum maksimal memanfaatkan adminitrasi pembelaran dalam proses pembelajaran sesuai dengan perencanaan yang telah dibuat.

Revisi Rancangan, Pelaksanaan kegiatan pembinaan pada siklus I ini masih terdapat kekurangan, sehingga perlu adanya revisi untuk dilakukan pada siklus berikutnya: 1) Kepala Sekolah perlu lebih sering dalam memberikan memotivasi dan mengarahkan guru dalam menyusun administrasi pembelajaran sehinga setiap guru memiliki administrasi pembelajaran sesuai dengan ketentuan dalam kurikulum yang berlaku. 2) Kepala sekolah hendaknya melakukan supervisi secara rutin sesuai dengan ketentuan minimal 1 kali pertriwulan. 3) Guru hendaknya lebih bersemangat dan banyak belajar dalam penyusunan adminitrasi pembelajaran baik lewat sosial media, kepala sekolah atau sesama guru/teman sejawat. 4) Guru hendaknya melaksanakan atau mewujudkan administrasi pembelajan yang telah dibuat dalam proses pembelajaran agar proses pembelajaran sesuai dengan perencanaan yang telah dibuat.

\section{Siklus II}

Tahap perencanaan, Pada tahap ini peneliti mempersiapkan perangkat pembinaan yang terdiri dari rencana pembinaan, lembar observasi dan alat-alat pembinaan yang mendukung.

Tahap kegiatan dan pelaksanaan, Pelaksanaan kegiatan pembinaan untuk siklus II dilaksanakan pada tanggal 30 Agustus s.d 11 September 2021 di SDN 2 Wanasaba Daya kecamatan Wanasaba Kabupaten Lombok Timur tahun pelajaran 2021/2022, dalam hal ini peneliti bertindak sebagai kepala sekolah. Adapun proses pembinaan mengacu pada rencana pembinaan dengan memperhatikan revisi pada siklus I, sehingga kesalahan atau kekurangan pada siklus I tidak terulang lagi pada siklus II. Pengamatan (observasi) dilaksanakan bersamaan dengan pelaksanaan belajar mengajar. 
Pada akhir proses pembinaan, guru dan kepala sekolah menyepakati waktu supervisi di kelas dengan tujuan untuk mengetahui peningkatan kemampuan guru dalam proses pembinaan yang telah dilakukan. Instrumen yang digunakan adalah tes formatif II. Adapun data hasil penelitian pada siklus II adalah sebagai berikut :

Tabel 2 Distribusi Skor Hasil Supervisi Akademik Pada Siklus II

\begin{tabular}{llccc}
\hline & & \multicolumn{3}{c}{ Keterangan } \\
No Nama Guru & Skor & Tuntas & Tidak Tuntas \\
& & & $\sqrt{ }$ & \\
2 & Sahibul Fadli, S.Pd.I. & 83 & $\sqrt{ }$ & \\
3 & Subki, S.Pd. & 90 & $\sqrt{ }$ & - \\
Jumlah Nilai & 81 & - & - \\
Nilai rata-rata S.Pd.SD & 254 & - & - \\
\% Jumlah Guru Yang & $100 \%(=3$ guru $)$ & \\
Mencapai nilai Supervisi \\
Akademik minimal 75
\end{tabular}

Dari tabel di atas diperoleh nilai rata-rata peningkatan kemam puan guru adalah 85 dan ketuntasan pembinaan mencapai $100 \%$ atau semua guru yang dijadikan sasaran penelitian sudah meningkat kompetensinya. Hasil ini menunjukkan bahwa pada siklus II ini ketuntasan belajar $100 \%$ Dari data-data yang telah diperoleh dapat duraikan sebagai berikut : 1) Selama proses pembinaan kepala sekolah telah melaksanakan semua pembinaan dengan baik. Meskipun ada beberapa aspek yang belum sempurna, tetapi persentase pelaksanaannya untuk masing-masing aspek cukup besar. 2) Berdasarkan data hasil pengamatan diketahui bahwa guru sudah melaksanakan proses pembelajaran sesuai dengan rencana yang telah dibuat. 3) Kekurangan pada siklus-siklus sebelumnya sudah mengalami perbaikan dan peningkatan sehingga menjadi lebih baik. 4) Hasil pembinaan guru oleh kepala sekolah melalui supervisi akademik pada siklus II mencapai ketuntasan $100 \%$.

Pada siklus II guru yang menjadi sample dalam penelitian ini telah menyusun administrasi pembelajaran dengan baik melalui supervisi yang dilakukan oleh kepala sekolah dan bisa memanfaatkannya secara maksimal dalam proses pembelajaran. Maka tidak diperlukan revisi terlalu banyak, namun yang perlu diperhatikan untuk tindak lanjutnya adalah memaksimalkan dan mempertahankan apa yang telah dimiliki sehingga tujuan pembelajaran dapat tercapai.

Setelah dilakukan tindakan pada siklus I dan siklus II menunjukkan hasil sebagai berikut

Tabel 3 Analisis Hasil Observasi Kemampuan Guru Pada Siklus I dan Siklus II Melalui Supervisi Akademik

\begin{tabular}{llcc}
\hline No & \multicolumn{1}{c}{ Nama } & $\begin{array}{c}\text { Skor Perolehan } \\
\text { Pada Siklus I }\end{array}$ & $\begin{array}{c}\text { Skor Perolehan } \\
\text { Pada Siklus II }\end{array}$ \\
\hline 1 & Sahibul Fadli, S.Pd.I. & 67 & 83 \\
2 & Subki, S.Pd. & 78 & 90 \\
3 & Nurhayani, S.Pd.SD & 75 & 81 \\
Jumlah Nilai & 220 & 254 \\
Nilai rata-rata & 73 & 85 \\
\% Jumlah Guru Yang Mencapai nilai & $66,67 \%$ & $100 \%$ \\
supervisi akademik minimal 75 & $(2$ guru $)$ & $(3$ guru) \\
\hline
\end{tabular}

Dari hasil analisis tersebut dapat disimpulkan bahwa : a) Terjadi peningkatan rata-rata hasil kompetensi guru dari siklus I ke siklus II yaitu dari $73 \%$ menjadi $85 \%$ ada kenaikan sebesar $=12 \%$. b) Terjadi peningkatan jumlah guru yang mencapai hasil Kemampuan $\geq 75$ dari 
siklus I ke siklus II yaitu dari 2 orang menjadi 3 orang dengan persentase awal 66,67\% menjadi 100\%. Hal ini menunjukkan bahwa semua sasaran telah mencapai ketuntasan.

\section{Pembahasan}

Hasil tindakan supervisi memberikan gambaran pada kondisi awal siklus I menunjukkan temuan skor kemampuan guru dalam penyusunan administrasi pembelajaran kondisi awal 66,67\% pada setelah dilakukan tindakan supervisi terjadi peningktan pada siklus kedua menjadi $100 \%$.

Berdasarkan hasil penelitian ini menunjukkan bahwa kompetensi guru dalam menyusun administrasi pembelajaran melalui supervisi akademik oleh kepala sekolah memiliki dampak positif dalam meningkatkan kemampuan guru. Hal ini dapat dilihat dari semakin mantapnya pemahaman guru dari pembinaan yang diberikan oleh kepala sekolah (rata-rata hasil kemampuan guru meningkat dari siklus I, dan II) yaitu masing-masing $73 \%$ dan $85 \%$. Dan pada siklus II terjadi peningkatan tingkat kompetensi guru dalam penyusunan administrasi pembelajaran sebesar $12 \%$, Sementara itu jumlah guru yang mencapai nilai supervisi akademik minimal $\geq 75$, terjadi peningkatan dari $66,67 \%$ menjadi $100 \%$, terjadi kenaikan sebesar 33,33\%, penelitian tersebut telah mencapai keberhasilan.

Semua guru menunjukkan sikap yang baik dan termotivasi dalam menyusun administrasi mengajar dengan lengkap. Hal ini peneliti ketahui dari hasil pengamatan pada saat melakukan wawancara dan bimbingan penyusunan administrasi pembelajaran. Selanjutnya dilihat dari kompetensi guru dalam menyusun administrasi mengajar, terjadi peningkatan dari siklus 1 ke siklus 2 .

Adanya keseriusan para guru yang disupervisi akademik menghasilkan tidak hanya peningkatan kemampuan mengajar mereka, melainkan juga administrasi mengajar mereka lengkap sehingga dapat meningkatkan mutu pembelajaran. Pada siklus pertama semua guru mencantumkan identitas mata pelajaran dalam RPP penerapan model-model pembelajarannya (melengkapi RPP penerapan model-model pembelajarannya dengan identitas mata pelajaran). Pada siklus II guru tersebut mencantumkan identitas mata pelajaran dalam RPP dan melengkapi administrasi mengajar lainnya.

Dari analisis data di atas bahwa peningkatan kompetensi guru dalam menyusun administrasi pembelajaran melalui supervisi Akademik berhasil yang berarti proses kegiatan belajar mengajar lebih berhasil dan dapat meningkatkan kemampuan guru khususnya di SDN 2 Wanasaba Daya, oleh karenanya diharapkan kepada Bapak/Ibu guru hendaknya menindaklanjuti hasil penelitian ini dengan tetap termotivasi dalam menyusun administrasi pembelajaran dan dapat menuangkannya dalam proses pembelajaran di kelas.

Berdasarkan manajemen berbasis sekolah (MBS) dikatakan tuntas apabila guru telah mencapai nilai KKM sebesar 75 mencapai $\geq 83,33 \%$. Sedangkan pada penilitian ini, pencapaian nilai $\geq 75$ pada (siklus II) mencapai melebihi target yang ditetapkan dalam MBS yaitu mencapai $100 \%$.

\section{KESIMPULAN}

Berdasarkan hasil Penelitian yang telah dilakukan maka dapat disimpulkan bahwa Kompetensi Guru Dalam Menyusun Admisitrasi Pembelajaran Masa Pandemi Covid-19 dapat meningkat melalui Supervisi Akademik di SDN 2 Wanasaba Daya Kecamatan Wanasaba pada Semester Genap Tahun Pelajaran 2021/2022”. Jumlah peningkatan dari 66,67\% menjadi 100\%, dengan selisih peningkatan $33,33 \%$.

\section{DAFTAR PUSTAKA}

Astuti, S. (2016). Penerapan supervisi akademik untuk meningkatkan kompetensi guru dalam menyusun administrasi penilaian di sd laboratorium uksw. Scholaria: Jurnal Pendidikan dan Kebudayaan, 6(1), 117-126.

Fitrah, M. (2017). Peran kepala sekolah dalam meningkatkan mutu pendidikan. Jurnal Penjaminan Mutu, 3(1), 31-42. 
Gabena, P. (2017). Upaya Peningkatan Kompetensi Guru Dalam Menyusun Silabus dan RPP Melalui Supervisi Akademik yang Berkelanjutan di SD Negeri 0102 Barumun. Ristekdik: Jurnal Bimbingan dan Konseling, 2(1).

Hamid, A. (2017). Upaya Peningkatan Kompetensi Guru dalam Menyusun Perangkat Pembelajaran melalui Supervisi Akademik yang Berkelanjutan SDN 007 Panipahan Darat. Jurnal PAJAR (Pendidikan dan Pengajaran), 1(2), 277-289.

Kau, M. A. (2017). Peran Guru Dalam Mengembangkan Kreativitas Anak Sekolah Dasar. In Proceeding Seminar Dan Lokakarya Nasional Bimbingan Dan Konseling 2017 (pp. 157-166).

Manizar, E. (2015). Peran guru sebagai motivator dalam belajar. Tadrib, 1(2), 204-222.

Minsih, M. (2018). Peran guru dalam pengelolaan kelas. Profesi pendidikan dasar, 5(1), 20-27.

Mulia, D. S., \& Suwarno, S. (2016). PTK (Penelitian Tindakan Kelas) Dengan Pembelajaran Berbasis Kearifan Lokal Dan Penulisan Artikel Ilmiah Di Sd Negeri Kalisube, Banyumas. Khazanah Pendidikan, 9(2).

Sudirman, S. (2020). UPAYA PENINGKATAN KOMPETENSI GURU DALAM MENYUSUN SILABUS DAN RPP MELALUI SUPERVISI AKADEMIK YANG BERKELANJUTAN DI SMAN 1 SIMBORO KABUPATEN MAMUJU. Celebes Education Review, 2(2), 81-90.

Susetya, B. (2017). Meningkatkan kemampuan guru dalam menyusun silabus dan RPP melalui supervisi akademik di SD N Gambiran Yogyakarta Tahun 2016. Taman Cendekia: Jurnal Pendidikan Ke-SD-an, 1(2), 134-141.

Yuhana, A. N., \& Aminy, F. A. (2019). Optimalisasi peran guru pendidikan agama Islam sebagai konselor dalam mengatasi masalah belajar siswa. Jurnal Penelitian Pendidikan Islam,[SL], 7(1), 79-96. 